\title{
Pengaruh Struktur Modal Dan Volatilitas Laba terhadap Kualitas Laba PT. Bank Sumut
}

\section{Effect of Capital Structure and Profit Volatility on Profit Quality in PT. Bank Sumut}

\author{
Aditya Amanda Pane* \& Sari Nuzullina Rahmadhani \\ Program Studi Akuntansi, Fakultas Ekonomi dan Bisnis, Universitas Medan Area
}

*Coresponding Email: aditva.amanda.pane@gmail.com

\section{Abstrak}

Tujuan dari penelitian ini adalah untuk mengetahui pengaruh dari struktur modal dan volatilitas laba terhadap kualitas laba pada PT. Bank Sumut. Penelitian ini juga dilakukan untuk mengetahui bagaimana kondisi volatilitas laba dan kualitas laba pada PT. Bank Sumut selama 10 tahun terakhir. Proksi yang digunakan untuk mengukur struktur modal adalah leverage, volatilitas laba di proksikan dengan standard deviasi dari laba dan kualitas laba diproksikan dengan discretionary loan loss provisions. Sample yang digunakan dalam penelitian ini adalah laporan keuangan kuartal PT. Bank Sumut tahun 2010 sampai dengan semester pertama 2020. Metode analisis yang digunakan adalah regresi berganda. Dari hasil analisis regresi berganda diperoleh bahwa struktur modal berpengaruh negative signifikan terhadap kualitas laba dan volatilitas laba tidak berpengaruh signifikan terhadap kualitas laba pada PT. Bank Sumut. Secara simultan, struktur modal dan volatilitas laba berpengaruh signifikan terhadap kualitas laba pada PT. Bank Sumut.

Kata Kunci: Struktur Modal; Volatilitas Laba; Kualitas Laba.

\begin{abstract}
The purposes of this research was to determined the influence of the capital structure and earnings volatility on the earnings quality PT. Bank Sumut. This research also aims to assess how the condition of the capital structure, earnings volatility and earnings quality at PT. Bank Sumut for 10 years lately. The proxy of capital structure is leverage, earnings volatility is standard deviasi of earnings and for the earnings quality the proxy is discretionary loan loss provisions. The samples used in this study are the quarterly financial statement of PT. Bank Sumut for the period of 2010 until the first semester of 2020. The analytical method used was multiple regression analysis. The result show that the capital structure has a negative significant effect on the earnings quality and earnings volatility does not has a significant effect on the earnings quality in PT. Bank Sumut. Meanwhile, the capital structure and earnings volatility simultaneous have a significant effect on the earnings quality.
\end{abstract}

Keywords: Capital Structure; Earnings Volatility; Earnings Quality.

How to Cite: Pane, A.A., \& Rahmadhani, S.N. (2021). Pengaruh Struktur Modal, Volatilitas Laba Terhadap Kualitas Laba PT. Bank Sumut. Jurnal Akuntansi dan Bisnis : Jurnal Program Studi Akuntansi. 7 (1):81-89. 


\section{PENDAHULUAN}

Laba merupakan suatu informasi penting yang disajikan perusahaan bagi para stakeholder yang digunakan untuk menilai kinerja operasional perusahaan tersebut. Bagaimana sebuah perusahaan dapat menghasilkan laba dalam kegiatan operasinya bergantung berbagai macam faktor, salah satunya adalah kemampuan manajemen dalam meminimalkan dan mengelola risiko sehingga dapat memaksimalkan potensi laba yang dapat diperolah. Namun, pada kenyataannya tidak semua perusahaan dapat mempertahankan kondisi laba yang stabil dan terus meningkat. Volatilitas laba menjadi salah satu poin penilaian apakah kondisi laba perusahaan baik atau tidak. Laba yang relatif stabil menjadi indikasi bahwa perusahaan dalam keadaan operasional yang baik dan stabil sehingga memberikan keyakinan bagi para investor bahwa perusahaan dapat mengelola risiko yang dihadapi perusahaan (Baskoro dan Wardhani, 2014).

Adanya gab informasi antara pemilik informasi dan pengguna informasi keuangan tersebut, menjadi celah bagi pihak internal untuk dapat memunculkan citra positif perusahaan bagi para stakeholder dengan menyajikan informasi laba sesuai dengan harapan. Hal ini akan mempengaruhi rendahnya kualitas laba yang dilaporkan oleh perusahaan tersebut. Penyajian laba yang tidak sesuai dengan kondisi sebenarnya akan menyesatkan para pembaca laporan keuangan dan pengambilan keputusan. Fenomena ini disebut dengan manajemen laba (earning management).

Salah satu faktor yang dapat mempengaruhi perusahaan dalam mengelola labanya adalah struktur modal atau leverage. Struktur modal merupakan salah satu komponen rasio keuangan yang digunakan untuk menilai kemampuan perusahaan dalam mendanai kegiatan operasi nya dengan melihat porsi utang dari modal perusahaan. Semakin tinggi struktur modal sebuah perusahaan menunjukkan semakin tinggi tingkat utang perusahaan yang akan menyebabkan biaya yang semakin besar sehingga dapat mengurangi kemampuan perusahaan untuk menghasilkan laba. Tentunya laba yang kecil akan memperburuk kinerja operasional perusahaan dan dapat mendorong perusahaan untuk melakukan manajemen laba.

Beberapa penelitian terdahulu memberikan hasil yang tidak konsisten dari faktorfaktor yang mempengaruhi kualitas laba. Hasil penelitian yang dilakukan Warianto dan Rusiti (2014) menunjukkan bahwa ukuran perusahaan dan likuiditas berpengaruh negatif signifikan terhadap manajemen laba sedangkan struktur modal berpengaruh positif signifikan. Menurut penelitian Dewi dan Eveline (2017) EBTP (Earning Before tax and Provisons) berpengaruh negatif signifikan terhadap manajemen laba. Sedangkan menurut hasil penelitian Wijayanti dan Diyanti (2017) Volatilitas laba berpengaruh positif signifikan pada DAKRD untuk menentukan CKPN terkait dengan manajemen laba. Hasil penelitian Zahro (2014) volatilitas laba berpengaruh positif signifikan terhadap manajemen laba. Dong et. Al (2012) melakukan penelitian pada 14 komersial bank di Chine untuk meneliti EBTP terhadap Discretionary Loan Loss Provision dengan hasil terdapat pengaruh positif signifikan. Hasil penelitian Irawati (2012) menunjukkan bahwa struktur modal dan ukuran perusahaan berpengaruh positif signifikan terhadap kualitas laba sedangkan pertumbuhan laba dan likuiditas berpengaruh negatif signifikan terhadap kualitas laba.

\section{Kualitas Laba}

Kualitas laba diukur dengan akrual. Perusahaan dengan akrual yang tinggi menunjukkan laba perusahaan berkualitas rendah, demikian juga sebaliknya. Setidaknya ada tiga penjelasan yang berhubungan dengan kualitas laba, yaitu (1) interpretasi konvensional, akrual yang tinggi menandakan adanya manipulasi earnings oleh manajer, 
(2) akrual dapat menjadi indikator utama terhadap perubahan prospek perusahaan, tanpa manipulasi oleh manajer, dan (3) akrual juga dapat memprediksi return apabila pasar memandang akrual sebagai refleksi pertumbuhan mas a yang lalu (Siallagan, 2009). Lebih lanjut Chan et al. (2001) mengatakan bahwa akuntansi akrual, merupakan indikator yang utama terhadap earnings quality. Akrual menggambarkan perbedaaan pendapatan akuntansi perusahaan dan aliran kas yang mendasarinya. Akrual positif yang besar mengindikasikan bahwa pendapatan lebih tinggi dari pada aliran kas yang diperoleh perusahaan. Perbedaan ini muncul dikarenakan accounting convention, dan berapa banyak pendapatan dan biaya diakui.

Menurut Healy dalam Warianto dan Rusiti (2014) menyatakan bahwa manajemen suatu perusahaan dapat melakukan manajemen laba dengan dua cara, yaitu: a. Mengendalikan transaksi-transaksi akrual, transaksi yang tidak berpengaruh terhadap aliran kas masuk ataupun kas keluar. b. Mengubah kebijakan akuntansi dan manajemen harus menjelaskannya dalam disclosure pada laporan keuangan tahunan.

Pada sektor perbankan, manajer bank menggunakan loan loss provisions untuk mengukur kekuatan finansial bank dan sebagai salah satu acuan bank menentukan sikap dalam pengendalian risiko kredit perbankan. Menurut Zoubi dan Al-Khazali (2007) loan loss provisions telah menjadi alat untuk perataan laba di dunia perbankan. Menurut Norden dan Stoian (2013) perusahaan perbankan menggunakan loan loss provisions untuk meratakan labanya karena loan loss provisions merupakan salah satu akun akrual yang dapat dimanipulasi oleh perusahaan sehingga laba dapat menjadi lebih tinggi atau rendah. Perusahaan dapat memanfaatkan unsur subyektivitas dalam membuat estimasi penilaian loan loss provisions.

Bank Indonesia menentukan besarnya penyisihan dalam batasan persentase tertentu, namun pihak manajemen bank masih diberikan kebebasan untuk menentukan kualitas aset berdasarkan ketentuan yang diatur dalam peraturan Bank Indonesia dan membentuk cadangan loan loss provisions melebihi cadangan yang wajib dibentuk. Dengan kata lain sangat memungkinkan loan loss provisions dijadikan obyek oleh perusahaan dalam melakukan perataan laba atau terjadi discretionary loan loss provisions di dalam perusahaan dalam upaya meratakan laba perusahaan.

\section{Struktur Modal}

Leverage adalah analisis untuk mengukur sejauh mana kegiatan operasional perusahaan dibiayai dengan hutang. Analisis ini digunakan untuk mengukur seberapa banyak dana yang diberikan oleh pemilik perusahaan dalam proporsinya dengan dana yang diperoleh dari kreditur perusahaan atau untuk mengukur sampai berapa jauh perusahaan telah dibiayai dengan utang-utang jangka pendek dan jangka panjangnya. Menurut Dira dan Astika (2014) bahwa semakin tinggi hutang perusahaan, maka perusahaan tersebut semakin dinamis. Pihak manajemen lebih terpacu untuk meningkatkan kinerjanya agar hutang-hutang perusahaan dapat terpenuhi sehingga dampak positifnya adalah perusahaan lebih berkembang.

Warianto dan Rusiti (2014) mengemukakan bahwa perusahaan yang memiliki hutang yang tinggi bisa berdampak pada risiko keuangan yang semakin besar. Risiko keuangan yang dimaksud adalah kemungkinan perusahaan tidak mampu membayar utang-utangnya. Adanya risiko gagal bayar ini menyebabkan biaya yang harus dikeluarkan perusahaan untuk mengatasi hal tersebut semakin besar sehingga akan menurunkan laba perusahaan. Oleh karena itu, jika tingkat leverage suatu perusahaan tinggi maka akan 
memiliki kecenderungan untuk melakukan manajemen laba yang besar sehingga kualitas laba yang dihasilkan menjadi rendah.

\section{Volatilitas Laba}

Bank beroperasi dengan berbagai tujuan dan salah satu tujuan yang akan dicapai adalah laba. Volatilitas sendiri menurut Ghozali (2007) merupakan variasi dari besarnya return yang diterima. Sehingga volatilitas laba dapat diartikan sebagai variasi besarnya laba yang dihasilkan perusahaan. Variasi atau ketidakpastian laba ini merupakan sebuah risiko yang dihadapi oleh bank. Couto (2002) mengemukakan bahwa volatilitas laba bank merupakan hal yang penting dan dapat menjadi indikator awal mengenai ketidakpastian akan modal dan likuiditas serta potensi terjadinya kegagalan/bangkrutnya bank. Volatilitas laba yang tinggi menunjukkan kualitas manajemen yang kurang begitu baik dan risiko yang tinggi dari bank tersebut.

Wijayanti dan Diyanti (2017) volatilitas laba yang semakin besar akan menurunkan kualitas laba yang dilaporkan. Hal ini disebabkan laba yang cenderung berfluktuasi akan menyulitkan pengguna laporan keuangan dalam memprediksi laba perusahaan di masa depan. Estimasi laba dapat menjadi bias dan menjadi tidak akurat pada kondisi laba yang berfluktuasi. Laba yang stabil adalah hal yang penting bagi bank, karena volatilitas laba yang tinggi pada satu bank dapat menimbulkan efek domino, volatilitas laba yang tinggi menyebabkan kinerja bank menurun dan berdampak pada aspek lain, seperti meningkatnya risiko likuiditas dan reputasi bank. Oleh karena itu, manajer di sektor perbankan dan regulator memiliki kepentingan untuk menjaga volatilitas laba minimum pada bank (Farook et al., 2014).

Dari teori di atas ditarik hipotesis dalam peneltian ini:

H01: Struktur modal berpengaruh signifikan terhadap kualitas laba

H02: Volatilitas Laba berpengaruh signifikan terhadap kualitas laba

H03: Struktur modal dan volatilitas laba secara simultan berpengaruh terhadap kualitas laba

\section{METODE PENELITIAN}

Jenis penelitian yang digunakan dalam penelitian ini adalah penelitian asosiatif yaitu untuk menganalisis pengaruh antara variabel independen terhadap variabel dependennya. Populasi dalam penelitian ini adalah Laporan Keuangan PT. Bank Sumut semua periode. Pemilihan sample dengan dengan menggunakan sample jenuh dimana terdapat sebanyak 41 laporan keuangan triwulan PT. Bank Sumut periode 2010 sampai dengan semester pertama 2020. Variabel dependen dalam penelitian ini adalah kualitas laba yang diproksikan dengan discretionary loan loss provisions. Variabel independen dalam penelitian ini adalah struktur modal dengan proksi leverage dan volatilitas laba dengan proksi standard deviasi laba sebelum pajak yang diskala dengan total asset. Untuk memperoleh kesimpulan dari penelitian ini, maka data yang diperoleh akan dilakukan analisis. Metode analisis yang digunakan dalam penelitian ini adalah analisis regresi berganda. Adapun operasionalisasi dari masing-masing variabel adalah:

Kualitas Laba. Laba adalah ukuran kinerja perusahaan. Namun, tidak semua angka yang dilaporkan sebagai laba mencerminkan kondisi perusahaan yang sebenarnya. Laba yang yang berkualitas adalah laba dapat digunakan oleh para stakeholder dalam proses pengambilan keputusan dan menghasilkan keputusan terbaik (Bernard dan Stober, 1989). Agar laba yang dihasilkan perusahaan berkualitas baik, manajemen cenderung melakukan manajemen laba, sehingga dalam laba yang dilaporkan setiap periode lebih stabil. 
Discretionary Loan Loss Provisons adalah salah satu indikator untuk menilai terjadinya manajemen laba di sebuah perusahaan.

Dalam Dong, et. al. (2012) loan loss provisons terdiri dari komponen yaitu discretionary loan loss provisins dan nondiscretionary loan loss provisions. Komponen discretionary LLP adalah bentuk langsung bahwa manajemen melakukan manjemen laba. Penelitian ini mengikuti model perhitungan pada penelitian Dewi dan Evelin (2014) yang juga merujuk pada penelitian terdahulu yang dilakukan oleh Kenagaretnam, et. al. (2003) dengan rumus:

$$
\begin{gathered}
\text { TA }=\mathrm{a}+\mathrm{b} 1 \text { NPL it-1 + b2 CHNPLit + b3 CHLOANit + e } \\
\text { NDA_LLPit = a + b1 NPL it-1 + b2 CHNPLit + b3 CHLOANit + e }
\end{gathered}
$$

Keterangan:

LLPit = (Cadangan Kerugian Penurunan Nilai) $/$ (Saldo awal Total Aset $)$

NPL it-1 = (Saldo kredit bermasalah) $/$ (Saldo awal total aset $)$

CHNPLit $=($ Perubahan kredit bermasalah $) /($ Saldo awal total aset $)$

CHLOANit $=($ Perubahan saldo kredit $) /($ Saldo awal total aset $)$

Selanjutnya nilai konstanta dan koefisien dari hasil regresi diatas digunakan untuk diperoleh nilai NDA_LLP. Kemudian, untuk memperoleh nilai discretionary accrual dari loan loss provisions adalah selisih dari Total Accruals (LLP) dengan Nondiscretionary Loan Loss Provisions.

$$
\text { DA_LLP }=\text { TA }- \text { NDA_LLP }
$$

Struktur Modal. Untuk mengukur kemampuan perusahaan dalam memenuhi kewajibannya. Pada penelitian ini struktur modal dinilai dari kemampuan modal perusahaan untuk membiayai segala kewajiban perusahaan.

Leverage $=($ total liabilitas $) /($ total ekuitas $)$

Volatilitas Laba. Volatilitas laba adalah bagaimana pergerakan laba yang diperoleh perusahaan setiap periodenya. Semakin tinggi volatilitas laba menggambarkan laba yang semakin tidak stabil. Perhitungan volatilitas laba pada penelitian ini adalah dengan menghitung standard deviasi dari laba sebelum pajak dan di skala dengan total asset.

\section{Uji Asumsi Klasik}

\section{HASIL DAN PEMBAHASAN}

Dari hasil pengujian atas uji normalitas dengan menggunakan metode Kolmogorov smirnov test diperoleh hasil $0.200>0.05$ sehingga dapat disimpulkan bahwa data pada penelitian ini berdistribusi normal. Untuk uji Multikolinearitas, diperoleh hasil nilai tolerance kedua variabel adalah 0.1 yaitu masing-masing sebesar 0.998 dan Variance Inflation Factor (VIF) di bawah 10 masing-masing 1.002 sehingga dapat disimpulkan bahwa tidak terjadi multikolinearitas variabel independen pada model regresi yang digunakan pada penelitian ini.

Selanjutnya untuk Autokorelasi, menggunakan uji Durbin Watson, dari hasil pengolahan data diperoleh nilai durbin Watson sebesr 1.712. Dengan kriteria dU $<\mathrm{DW}<$ 4-dU, diperoleh $1.459<1.712<2.541$, sehingga dapat disimpulkan bahwa data pada penelitian ini bebas dari autokorelasi. Hasil uji heteroskedastisitas atas data pada penelitian ini dilihat dari plot diagram dimana hasil plot diagram masing-masing variabel independen terhadap variabel dependen tidak menunjukkan pola tertentu atau menyebar 
sehingga dapat disimpulkan tidak terjadi heteroskedastisitas pada data dalam penelitian ini.

\section{Hasil Analisis Penelitian Model Regresi}

Model pada penelitian ini telah melalui uji asumsi klasik dan diperoleh kesimpulan bahwa model dapat dianalisis dengan menggunakan teknik analisis regresi berganda. Dari hasil regresi deperoleh hasil sebagai berikut:

Tabel 5 Model Regresi

\begin{tabular}{|c|c|c|c|c|c|}
\hline Model & Unstandardize B & $\begin{array}{c}\text { Coefficients } \\
\text { Std. Error }\end{array}$ & $\begin{array}{c}\text { Standardize } \\
\text { Coefficients Beta }\end{array}$ & $\mathrm{T}$ & Sig. \\
\hline Konstanta & 0.023 & 0.009 & & 2.496 & 0.017 \\
\hline Struktur Modal & -0.002 & 0.001 & -0.312 & -2.084 & 0.044 \\
\hline Volatilitas Laba & -0.205 & 0.145 & -0.212 & -1.414 & 0.166 \\
\hline
\end{tabular}

Sumber: data diolah, 2020

Persamaan regresi yang diperoleh pada model penelitian ini adalah sebagai berikut:

$\mathrm{Y}=0,023-0.002 \mathrm{X} 1-0.205 \mathrm{X} 2$

Kualitas Laba $=0.023-0.002$ Struktur Modal -0.205 Volatilitas Laba.

\section{Koefisien Korelasi dan Determinasi}

Table 6 Koefisien Korelasi dan Determinasi

\begin{tabular}{|c|c|c|}
\hline Variable & $\mathrm{R}$ & $\mathrm{R}^{2}$ \\
\hline Struktur Modal, Volatilitas Laba dan Kualitas Laba & 0.384 & 0.148 \\
\hline Kualitas Laba dan Struktur Modal & -0.321 & 0.103 \\
\hline Kualitas Laba dan Volatilitas Laba & -0.225 & 0.057 \\
\hline
\end{tabular}

Sumber: data diolah, 2020

Hasil di atas menjelaskan hubungan antara struktur modal dan volatilitas laba secara bersama-sama adalah sebesar 0.384. Nilai ini menunjukkan bahwa hubungan variabelvaribel tersebut positif dan kurang erat. Nilai koefisien determinasinya sebesar $14.8 \%$ artinya struktur modal dan volatilitas laba menjelaskan nilai dari kualitas laba adalah sebesar $14.8 \%$ sedangkan sisanya sebesar $83.2 \%$ dijelaskan oleh variable lain di luar model regresi yang digunakan pada penelitian ini. Untuk hubungan parsial antara struktur modal dan kualitas laba nilai koefisien korelasinya sebesar - 0.321, angka ini menunjukkan hubungan negatif dan kurang erat dengan nilai koefisien determinasi sebesar 0.102 atau 10.3\%. Artinya Struktur modal menjelaskan nilai kualitas laba secara parsial adalah $10.3 \%$ sisanya dijelaskan oleh volatilitas laba dan variable lain di luar model regresi. Untuk hubungan parsial antara volatilitas laba dengan kualitas laba adalah sebesar -0.225 , artinya hubungan kedua variable tersebut adalah negatif kurang erat. Dengan nilai koefisien determinasi sebsar 0.057 atau $5.57 \%$ artinya volatilitas laba dapat menjelaskan kualitas laba sebesar $5.57 \%$ sisanya dijelaskan oleh struktur modal dan variable lain di luar model regresi.

\section{Hasil Uji Hipotesis}

Tabel 7 Hasil Uji Hipotesis

\begin{tabular}{|c|c|c|c|}
\hline Model & $T$ & Sig. & Kesimpulan \\
\hline Struktur Modal & -2.084 & 0.044 & H01 ditolak \\
\hline Volatilitas Laba & -1.414 & 0.166 & H02 tidak dapat ditolak \\
\hline
\end{tabular}

Sumber: data diolah, 2020 
Hipotesis pertama pada model regresi ini untuk menguji pengaruh struktur modal terhadap kualitas laba. Hasil signifikansi yang diperoleh adalah sebesar 0.044 dimana nilai ini lebih kecil dengan kriteria pengujian sebesar 0.05 sehingga dapat disimpulkan bahwa hipotesis ditolak artinya terdapat pengaruh signifikan struktur modal terhadap kualitas laba. Struktur Modal memiliki nilai pengaruh negatif terhadap kualitas laba artinya apabila terjadi kenaikan pada struktur modal maka nilai DA_LLP akan mengalami penurunan yang mengindikasikan bahwa kualitas laba semakin baik karena semakin kecilnya angka manajemen laba yang dilakukan perusahaan. Hasil ini bertentangan dengan penelitian Warianto dan Rusti (2014) yang memperoleh struktur modal berpengaruh positif signifikan terhadap kualitas laba.

Hasil ini menunjukkan bahwa porsi utang yang tinggi dibandingkan modal pada PT Bank Sumut, digunakan untuk mengoptimalkan perolehan laba namun tidak berdampak pada terjadinya manajemen laba. Hasil ini juga mungkin disebabkan karena porsi leverage yang cukup tinggi pada PT Bank Sumut tersebut, dengan rata-rata diatas 200\%, dibandingkan dengan modal nya, porsi liabilitas sangat besar untuk mendanai kegiatan operasional perusahaan. Sehingga untuk meminimalisir risiko operasional yang terjadi dari tingginya porsi liabilitas dibandingkan modalnya tersebut, manajemen PT. Bank Sumut meminimalisir manajemen laba sehingga dapat meningkatkan kualitas laba yang dihasilkan perusahaan.

Hipotesis kedua pada penelitian ini adalah untuk menguji pengaruh volatilitas laba terhadap kualitas laba. Hasil signifikansi yang diperoleh adalah sebesar 0.166 dimana nilai ini lebih besar daripada kriteria pengujian sebasar 0.05 sehingga dapat diperoleh kesimpulan bahwa volatilitas laba tidak berpengaruh signifikan terhadap DA_LLP yang menjadi indikator menilai kualitas laba. Dari hasil deskriptif statitik, volatilitas laba PT Bank Sumut dari tahun 2010 sampai dengan semester pertama tahun 2020 dengan nilai rata-rata 0.029 dan standard deviasi sebesar 0.01 menunjukkan bahwa laba PT. Bank Sumut memiliki tingkat volatilitas yang cenderung rendah dan stabil karena selisih antara rata-rata data dengan standard deviasinya juga relatif rendah sekitar 1\%. Namum angka volatilitas laba tersebut tidak mempengaruhi kondisi kualitas laba PT. Bank Sumut secara signifikan.

Dari nilai koefisien yang diperoleh bernilai negatif menunjukkan bahwa hubungan antara volatilitas laba dan kualitas laba bernilai negatif dimana semakin tinggi volatilitas laba, maka nilai DA_LLP akan semakin rendah. Namun, hubungan ini tidak memberikan pengaruh yang signifikan. Hasil ini juga dilihat dari koefisien korelasi dan determinasi secara parsial dimana hubungan antara volatilitas laba dan kualitas laba kurang erat atau dinilai cukup lemah, sehinnga volatilitas laba pada PT. Bank Sumut tidak mempengaruhi Kualitas Laba yang dihasilkannya.

\begin{tabular}{|c|c|r|r|r|r|c|}
\multicolumn{2}{|c|}{ Tabel 8 Hasil Uji F } \\
\multicolumn{2}{|c|}{ Model } & $\begin{array}{c}\text { Sum of } \\
\text { Squares }\end{array}$ & Df & $\begin{array}{c}\text { Mean } \\
\text { Square }\end{array}$ & F & Sig. \\
\hline \multirow{2}{*}{1} & Regression & .001 & 2 & .000 & 3.295 & $.048^{\mathrm{b}}$ \\
\cline { 2 - 8 } & Residual & .004 & 38 & .000 & & \\
\cline { 2 - 8 } & Total & .004 & 40 & & & \\
\hline
\end{tabular}

Sumber: data diolah, 2020

Nilai signifikansi F pada model regresi ini adalah sebesar 0.048, angka ini lebih kecil dari kriteria penilaian sebesar 0.05 sehingga dapat disimpulkan bahwa secara simultan 
struktur modal dan volatilitas laba berpengaruh signifikan terhadap kualitas laba. Artinya secara bersama-sama struktur modal dan volatilitas laba dapat mempengaruhi nilai dari kualitas laba, jika dilihat koefisien korelasinya, hubungan antar struktur modal, volatilitas laba dan kualitas laba adalah positif dan kurang erat.

\section{SIMPULAN}

Penelitian ini memberikan hasil bahwa struktur modal berpengaruh negatif signifikan terhadap kualitas laba, dimana hasil perhitungan leverage yang menjadi indikator struktur modal menunjukkan nilai yang relatif tinggi, artinya PT. Bank Sumut memiliki porsi liabilitas yang cukup besar dalam mendanai kegiatan operasional nya dibandingkan dengan modal. Hal ini karena Bank memiliki fungsi dan tujuan untuk menghimpun dana dari masyarkat. Komponen terbesar dari liabilitas yang dimiliki oleh PT. Bank Sumut sendiri yaitu berupa dana dari pihak ketiga dalam bentuk giro, tabungan dan deposito. Hal ini lah yang menjadi alasan mengapa ketika struktur modal naik namun tidak menyebabkan manajemen laba di perusahaan semakin besar.

Volatilitas laba tidak berpengaruh signifikan terhadap kualitas laba, hasil ini bertentangan dengan penelitian terdahulu yang dilakukan oleh Wijayanti dan Diyanti (2017) serta Zahro (2014) dimana volatilitas laba berpengaruh positif terhadap kualitas laba. Dari hasil pengolahan data diperoleh bahwa angka manajemen laba yang terjadi pada PT. Bank Sumut rendah hal ini menunjukkan bahwa dari laporan keuangan tersebut tidak terdapat risiko manajemen laba dilakukan oleh PT Bank Sumut, serta fluktuasi atau volatilitas laba juga rendah. Volatilitas laba yang rendah ini juga menunjukkan bahwa selama 10 tahun dengan data laporan keuangan secara kuartal menunjukkan bahwa perolehan laba PT. Bank Sumut ralatif stabil dan tidak mengalami fluktuasi yang signifikan, namun volatilitas laba yang rendah tersebut tidak memberikan pengaruh yang signifikan terhadap manajemen laba yang rendah yang mengindikasikan kualitas laba yang baik. Secara bersama struktur modal dan volatilitas laba berpengaruh signifikan terhadap kualitas laba, hal ini menunjukkan bahwa secara bersama-sama kedua variabel tersebut akan mempengaruhi nilai dari kualitas laba yang dimiliki oleh PT. Bank Sumut.

\section{DAFTAR PUSTAKA}

Baskoro, M.P. dan Wardhani, R. (2014). Analisis Pengaruh Volatilitas Laba dan Manajemen Laba Riil dan Akrual Terhadap Kebijakan Investasi. Simposium Nasional Akuntansi 17. Mataram 24-27 September 2014.

Bernard, V.L. dan Stober, T.L. (1989). The Amount of Information Reflected in Cash Flows and Accruals. Working Paper 599. The University of Michigan.

Chan, K et al. (2001). Earning Quality and Stocks Returns. NBER Working Paper Series. www.nber.org/paper/w8303

Dewi P. I. dan Indriani, A. (2016). Analisis Faktor-Faktor yang Berpengaruh Terhadap Loan Loss Provisions. Journal Of Management. Vol. 5, No. 4: 1-12.

Dewi, S.P. dan Evelin. (2017). Faktor-Faktor yang Mempengaruhi Discretionary Loan Loss Provisions pada Perusahaan Perbankan yang Terdaftar di Bursa Efek Indonesia, Jurnal Manajemen. Vol. 11, No. 03: 434-453.

Dira, K.P. dan I.B.P. Atika. (2014). Pengaruh Struktur Modal, Likuiditas, Pertumbuhan Laba dan Ukuran Perusahaan pada Kualitas Laba. E-Jurnal Akuntansi Universitas Udayana. Vol. 7, No. 1: 64-78.

Dong, X., Jia Liu, Beibei Hu. (2012). Research on the Relationship of Commercial Bank's Loan Loss Provisons and Earning Management and Capital Management. Journal of Services Science and Management. Vol. 5: 171-179.

Ghozali, dkk. (2007). Intellectual Capital dan Kinerja Keuangan Perusahaan; Suatu Analisis dengan Pendepatan PLS. Simposium Nasional Akuntansi 11. Pontianak 23-24 Juli 2008.

Irawati, D.E. (2012). Pengaruh Struktur Modal, Pertumbuhan Laba, Ukuran Perusahaan dan Likuiditas terhadap Kualitas Laba, Accounting Analysis Journal. Vol. 26, No. 1: 19-32.

Karim, Nina K., Siti Atikah dan Indria P. L. (2019). Kualitas Laba dan Pengukurannya pada Perusahaan Jasa Pendukung Industri Pariwisata. Jurnal Aplikasi Akuntansi. Vol. 4, No. 1: 1-14.

Komalasari, P. T. dan I Gede Adi P. (2015). Kualitas Laba dan Pengaruhnya terhadap Keputusan Investasi, Jurnal Ekonomi dan Bisnis. Vol.25, No. 2: 125-134 
Norden, L., and Anamaria Stoain. (2014). Bank Earnings Management through Loan Loss Provisions: A Doubleedged Sword?. De Nederlandsche Bank Working Paper, No. 404.

Siallagan, H. (2009). Pengaruh Kualitas Laba terhadap Nilai Perusahaan. Jurnal Akuntansi Kontemporer. Vol. 1 , No. 1: $21-32$.

Surifah. (2010). Kualitas Laba dan Pengukurannya. Jurnal Ekonomi. Vol. 8, No. 2: 31-47.

Warianto, P., dan Rusiti, Ch. (2014). Pengaruh Ukuran Perusahaan, Struktur Modal, Likuiditas dan Investment Opportunity Set (IOS) terhadap Kualitas Laba pada Perusahaan Manufaktur yang Terdaftar di BEI. Modus, Vol. 26, No. 1: 19-32.

Wijayanti, R., dan Diyanti, V. (2017). Pengaruh Volatilitas Laba, Perataan Laba dan Corporate Governance terhadap Kualitas Laba Bank Syariah dan Konvensional. Jurnal Akuntansi dan Investasi.Vol. 18, No. 1: 66-79.

Zahro, M. (2014). Akuntansi Nilai Wajar, Volatilitas Laba dan Praktik Manajemen Laba pada Perusahaan Perbankan. Jurnal Ilmu dan Riset Akuntansi. Vol. 3, No. 11:1-24.

Zoubi T. A. dan Osamah, A. (2007). Empirical Testing of the Loss Provisions of Banks in the GCC Region. Managerial Finance. Vol. 33: 500-511. 